Neuro Images

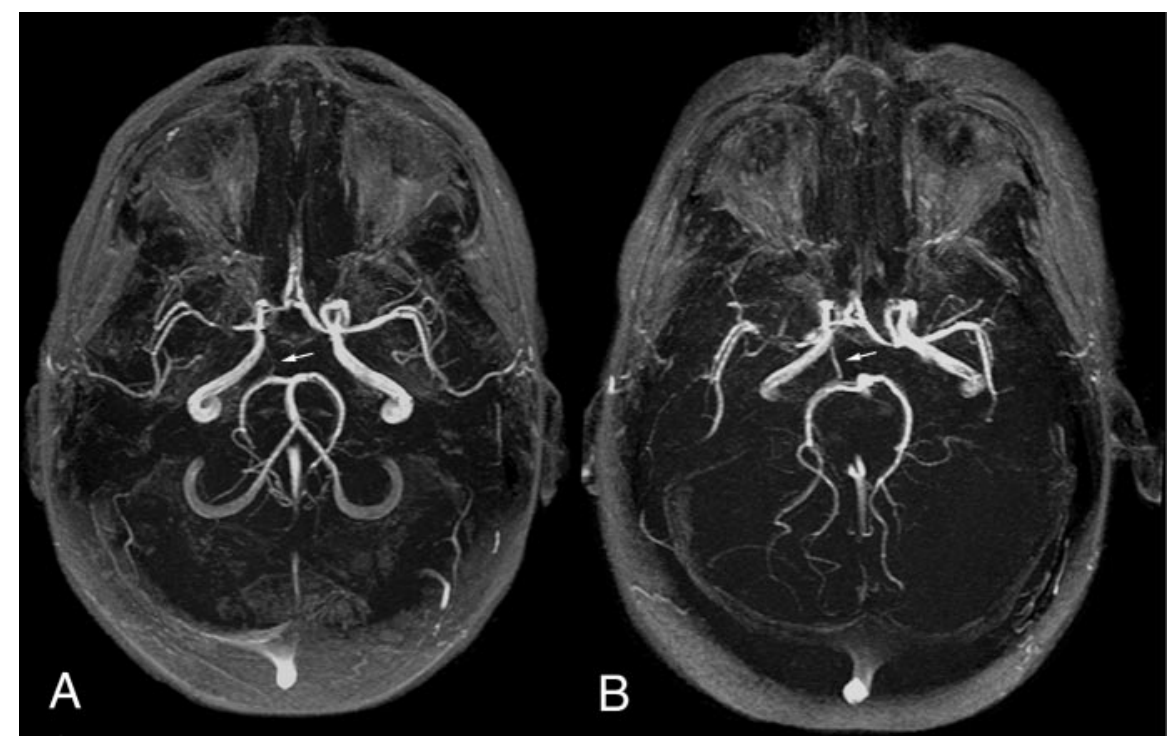

Figure. Serial MR angiography revealing progressive right middle cerebral artery stenosis (A, initial; B, two months later) and interval collateral recruitment of the right posterior communicating artery (arrows).

\section{Willisian collateralization}

David S. Liebeskind, MD; and Lauren H. Sansing, MD, Philadelphia, PA

Serial MR angiography (MRA) of a woman aged 31 years with moyamoya demonstrated progressive stenosis of the right middle cerebral artery with collateralization of a hypoplastic right posterior communicating artery ( $\mathrm{PCoA}$; figure, arrows). Willisian collaterals are considered primary sources of collateral blood flow

Address correspondence and reprint requests to Dr. David S. Liebeskind, Comprehensive Stroke Center and Department of Neurology, University of Pennsylvania, 3 West Gates Building, 3400 Spruce Street, Philadelphia, PA 19104-4283; e-mail: davidliebeskind@yahoo.com recruited at the onset of ischemia, yet PCoA hypoplasia (diameter, $<0.8 \mathrm{~mm}$ on MRA) may preclude collateral compensation. ${ }^{1}$ Willisian collateralization of a hypoplastic PCoA suggests that PCoA hypoplasia is not a static feature. Dynamic anatomic and physiologic changes of such primary Willisian collaterals suggest secondary collateral potential. Moyamoya PCoA dilatation may indicate disease progression and portend hemorrhagic sequelae. ${ }^{2}$

1. Hartkamp MJ, van der Grond J, van Everdingen KJ, Hillen B, Mali WP Circle of Willis collateral flow investigated by magnetic resonance angiography. Stroke 1999;30:2671-2678.

2. Morioka M, Hamada J, Kawano T, et al. Angiographic dilatation and branch extension of the anterior choroidal and posterior communicating arteries are predictors of hemorrhage in adult moyamoya patients. Stroke 2003;34:90-95. 


\section{Neurology}

Willisian collateralization

David S. Liebeskind and Lauren H. Sansing

Neurology 2004;63;344

DOI 10.1212/01.WNL.0000134624.45563.52

This information is current as of July 26, 2004

\section{Updated Information \&} Services

\section{References}

Citations

Subspecialty Collections

\section{Permissions \& Licensing}

Reprints including high resolution figures, can be found at: http://n.neurology.org/content/63/2/344.full

This article cites 2 articles, 2 of which you can access for free at: http://n.neurology.org/content/63/2/344.full\#ref-list-1

This article has been cited by 3 HighWire-hosted articles: http://n.neurology.org/content/63/2/344.full\#\#otherarticles

This article, along with others on similar topics, appears in the following collection(s):

\section{All Imaging}

http://n.neurology.org/cgi/collection/all_imaging

\section{MRI}

http://n.neurology.org/cgi/collection/mri

Subarachnoid hemorrhage

http://n.neurology.org/cgi/collection/subarachnoid_hemorrhage

Information about reproducing this article in parts (figures,tables) or in its entirety can be found online at:

http://www.neurology.org/about/about_the_journal\#permissions

Information about ordering reprints can be found online: http://n.neurology.org/subscribers/advertise

Neurology ${ }^{\circledR}$ is the official journal of the American Academy of Neurology. Published continuously since 1951, it is now a weekly with 48 issues per year. Copyright. All rights reserved. Print ISSN: 0028-3878. Online ISSN: 1526-632X.

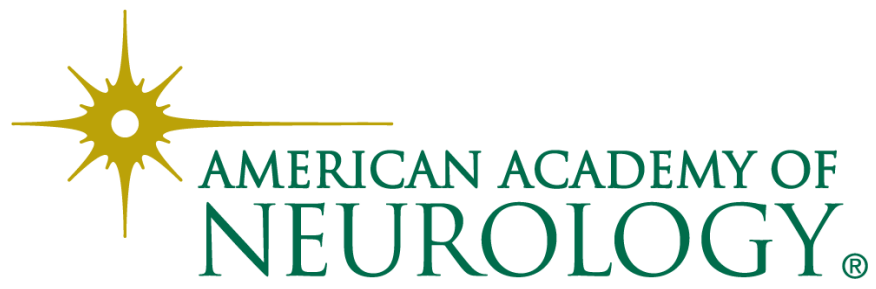

